\title{
Gambaran Kontainer Potensial dan Kondisi Lingkungannya sebagai Tempat Perindukan Nyamuk di Universitas Padjadjaran Jatinangor
}

\author{
Lia Faridah, Muhammad Ersyad Hamda, Neneng Syarifah Syafei, Yukan Niko Agrianfanny \\ Departemen Mikrobiologi dan Parasitologi Fakultas Kedokteran Universitas Padjadjaran, Bandung, Indonesia
}

\begin{abstract}
Abstrak
Nyamuk memiliki peran penting sebagai vektor penyakit menular seperti demam berdarah dengue, malaria, filariasis, demam kuning, dan chikungunya sehingga keberadaan nyamuk perlu dikontrol. Pengawasan tempat perindukan nyamuk akan membantu pihak berwenang untuk merancang pengendalian kepadatan nyamuk. Pertumbuhan larva nyamuk dipengaruhi oleh kondisi lingkungan seperti suhu air, kelembapan udara, dan $\mathrm{pH}$ air. Kondisi tersebut dapat bervariasi karena perbedaan geografis, variasi musiman, atau bahkan perubahan iklim.Tujuan penelitian ini adalah mengetahui kontainer potensial dan kondisi lingkungannya sebagai tempat perindukan nyamuk di Universitas Padjadjaran Jatinangor. Penelitian deskriptif dilakukan dengan mengamati larva nyamuk dalam wadah air baik di dalam maupun di luar gedung fakultas. Kondisi lingkungan $(\mathrm{pH}$, suhu dan kelembapan) diukur dan dicatat selama pengamatan untuk setiap kontainer. Hasil penelitian menunjukkan bahwa dari 582 kontainer yang diteliti terdapat $72(12,4 \%)$ positif larva nyamuk. Kontainer yang paling potensial di dalam bangunan adalah ember, sedangkan di luar bangunan adalah bambu Aedes sp. Mendominasi penemuan larva di lapangan. Suhu air rerata yang diperoleh adalah $24,3^{\circ} \mathrm{C}$, kelembapan $66,7 \%$ dan pH 8,1. Kondisi suhu dan $\mathrm{pH}$ sesuai dengan kondisi optimum perkembangan larva pada umumnya. Sementara tingkat kelembapan yang lebih rendah (kelembapan 81,6-89,5\%) masih mampu membuat larva nyamuk tumbuh dengan baik di Universitas Padjadjaran Jatinangor.
\end{abstract}

Kata kunci: Kelembapan, larva nyamuk, pH, suhu air, Universitas Padjadjaran

\section{Potential Container and Its Environmental Conditions for Mosquito Breeding Site in Universitas Padjadjaran Jatinangor}

\begin{abstract}
Playing pivotal role as vector of infectious disease such as dengue hemorrhagic fever, malaria, filariasis, yellow fever and chikungunya, mosquito needs to be controlled. Surveillance for mosquito breeding places will help the authorities in devising means in controlling mosquito density. The growth of mosquito larvae is influenced by environmental conditions such as water temperature, humidity, and $\mathrm{pH}$. Those conditions may vary due to geographic differences, seasonal variations, or even climate change. The purpose of this study was to understand the potential container and its environmental conditions for larvae in Universitas Padjadjaran Jatinangor. A descriptive study was conducted by observing the presence of mosquito larvae in water containers both inside and outside of faculty buildings. Environmental conditions ( $\mathrm{pH}$, water temperature and humidity) were measured and recorded during observation for each water container. Results showed that from 582 containers examined, $72(12.4 \%)$ were positive for larvae. The most potential container in the building was bucket, while foroutside of the building, the most potential container was bamboo. Aedes sp. dominated larvae discovered in this study. The average water temperature obtained was $24.30 \mathrm{C}$ with $66 \%$ humidity, and $\mathrm{pH} 8.1$. These temperature and $\mathrm{pH}$ values are the optimum condition for larvae development in general. However, lower humidity level (humidity 81.6-89.5\%) can still enable good growth of mosquito's eggs in the campus area of Universitas Padjadjaran Jatinangor.
\end{abstract}

Key words: Humidity, mosquito larvae, pH, water temperature, Universitas Padjadjaran

Korespondensi: Muhammad Ersyad Hamda, dr., M.Kes, Departemen Mikrobiologi dan Parasitologi Fakultas Kedokteran Universitas Padjadjaran, Jalan Bandung-Sumedang KM.21 Jatinangor, Email m.ersyad.hamda@unpad.ac.id 


\section{Pendahuluan}

Nyamuk merupakan vektor penyebar beberapa penyakit infeksi seperti demam berdarah dengue (DBD), malaria, filariasis, dan demam kuning, serta chikungunya. ${ }^{1}$ Jawa Barat sebagai salah satu provinsi di Indonesia merupakan wilayah dengan incidence rate (IR) dan case fatality rate (CFR) penyakit tular vektor yang tergolong cukup tinggi. Berdasarkan laporan jumlah kasus penyakit kabupaten/kota Provinsi Jawa Barat tahun 2012, Kabupaten Sumedang Provinsi Jawa Barat memiliki 554 kasus dengue, 33 kasus malaria, 1 kasus filariasis dan 48 kasus KLB suspek chikungunya. Pada tahun tersebut kasus dengue tertinggi terjadi di Kecamatan Jatinangor. ${ }^{2}$

Karakteristik habitat dari perkembangbiakan nyamuk penyebar penyakit infeksi ini sangat beragam. Nyamuk mampu berkembang biak di dalam air bersih maupun air kotor baik pada kontainer yang alami maupun buatan., ${ }^{1,3}$ Penelitian dari berbagai negara menunjukkan bahwa ketersediaan kontainer penampung air yang menggenang mampu memengaruhi idensitas nyamuk di suatu daerah sehingga meningkatkan risiko peningkatan penyakit tular vektor. ${ }^{4,5}$ Sampai saat ini vaksin dan obat mulai ditemukan untuk pencegahan dan pengobatan, namun pengendalian lingkungan dengan cara pemberantasan sarang nyamuk tetap menjadi cara yang paling efektif untuk dilakukan.

Selain ketersediaan kontainer, pertumbuhan nyamuk juga dapat dipengaruhi oleh kondisi lingkungan seperti suhu air, kelembapan, dan juga $\mathrm{pH}$ air. Kondisi tersebut dapat bervariasi karena perbedaan geografis, variasi musiman, atau bahkan perubahan iklim. ${ }^{1,6}$ Di Universitas Padjadjaran Jatinangor belum tersedia data evaluasi maupun penelitian paling baru terkait tempat perindukan nyamuk. Berdasar atas hal tersebut maka penelitian mengenai kontainer potensial untuk perindukan nyamuk serta kondisi lingkungannya dilakukan sebagai data awal untuk upaya pencegahan penyebaran penyakit infeksi yang ditularkan oleh nyamuk.

\section{Metode}

Penelitian ini merupakan penelitian deskriptif yang dilakukan selama 4 bulan, yaitu Mei sampai Agustus 2017. Daerah survei adalah 16 fakultas yang berada di Universitas Padjadjaran Jatinangor (Tabel 1). Sebanyak 581 kontainer baik di dalam maupun di luar dengan total 71 bangunan telah diobservasi untuk mengetahui keberadaan jentik nyamuk. Dalam penelitian ini area luar bangunan fakultas terbatas pada daerah sekitar gedung dengan radius 100 meter. Izin penelitian telah disetujui oleh fakultas masing-masing.

Jentik diambil menggunakan pipetplastik $3 \mathrm{~mL}$ dan jaring bertangkai panjang apabila kontainer penampung air berukuran besar. Sampel jentik yang didapatkan kemudian dimasukkan ke dalam botol plastik dan dikirim ke laboratorium Parasitologi Fakultas Kedokteran Universitas Padjadjaran untuk identifikasi genus.

Kondisi lingkungan diukur pada tiap-tiap wadah secara bersamaan dengan pengamatan jentik. Suhu air dan $\mathrm{pH}$ air diukur dengan menggunakan instrumen digital Luthron WA2017SD, sedangkan kelembapan diukur dengan menggunakan higrometer Luthron LM-8000A. Kalibrasi instrumen selalu dilakukan sebelum digunakan. Data yang terkumpul selanjutnya akan dianalisis menggunakan perangkat lunak Microsoft Excel 2010 dan SPSS 22.

\section{Tabel 1 Lokasi Sampling}

\begin{tabular}{clcl}
\hline No & \multicolumn{1}{c}{ Fakultas } & No & Fakultas \\
\hline 1 & Kedokteran & 9 & Ilmu Budaya \\
2 & Kedokteran Gigi & 10 & Psikologi \\
3 & Ilmu Sosial dan Ilmu Politik & 11 & Ilmu Komunikasi \\
4 & Peternakan & 12 & MIPA \\
5 & Farmasi & 13 & Pertanian \\
6 & Hukum & 14 & Keperawatan \\
7 & Perikanan dan Kelautan & 15 & Teknik Geologi \\
8 & Teknologi Industri Pertanian & 16 & Ekonomi dan Bisnis \\
\hline
\end{tabular}




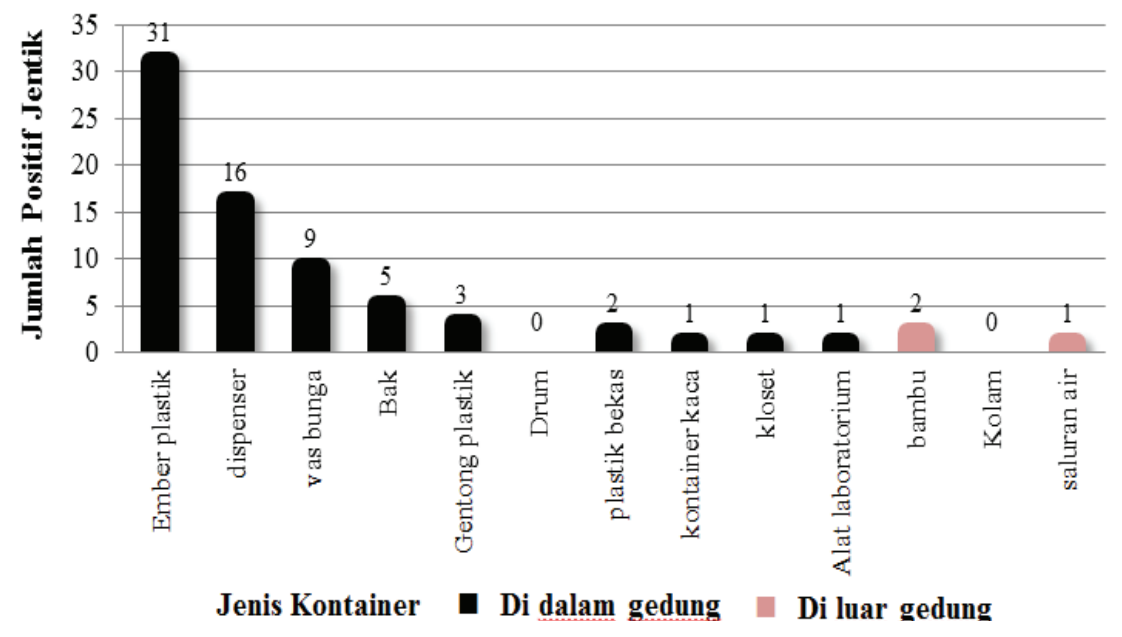

Gambar Distribusi Jentik Berdasarkan Lokasi dan Jenis Kontainer yang Ditemukan

\section{Hasil}

Hasil observasi tempat-tempat perindukan nyamuk terlihat pada Gambar 1 . Di antara 582 kontainer yang diperiksa terdapat $72(12,2 \%)$ kontainer yang ditemukan jentik nyamuk dengan proporsi sebagai berikut: ember plastik 31 buah $(43,1 \%)$, dispenser $16(22,2 \%)$, vas bunga $(12,5 \%)$, bak $5(6,9 \%)$, gentong plastik $3(4,2 \%)$, plastik bekas $2(2,8 \%)$, kontainer kaca $1(1,4 \%)$, kloset $1(1,4 \%)$, alat laboratorium $1(1,4 \%)$, bambu $2(2,8 \%)$, dan saluran air $1(1,4 \%)$.

Hasil identifikasi larva menunjukkan dari seluruh kontainer positif ditemukan 54 (75\%) kontainer menjadi tempat perindukan Aedes aegypti, 13 (18,1\%) Aedes albopictus dan 5 (6,9\%) Culex sp. Hasil pengukuran lingkungan (Tabel 2) didapatkan rerata $\mathrm{pH}$ air pada kontainer yang diperiksa adalah 8,1 , suhu air $24,3^{\circ} \mathrm{C}$, dan kelembapan udara $66,7 \%$.

\section{Pembahasan}

Penelitian yang telah dilakukan di Universitas Padjadjaran Jatinangor memperlihatkan bahwa kontainer di dalam gedung lebih dominan ditemukan sebagai tempat pembiakan nyamuk daripada kontainer di luar gedung. Hasil penelitian ini sejalan dengan penelitian Riandi dkk. $^{3}$ di kota Tasikmalaya yang menunjukkan bahwa jentik nyamuk lebih banyak ditemukan pada kontainer di dalam rumah dibanding dengan luar rumah. Perbedaan kedua penelitian ini adalah pada jenis kontainer yang ditemukan. Di Tasikmalaya jentik relatif sedikit ditemukan dalam ember (3\%) karena ember sering digunakan sehari-hari, terawasi, dan memiliki siklus pengurasan yang relatif singkat sehingga cukup sulit bagi jentik untuk berkembang biak, sedangkan di Universitas Padjadjaran ember menjadi kontainer yang paling dominan positif jentik. Keadaan ini terjadi karena berdasar atas hasil observasi di lapangan, terdapat toilet fakultas yang jarang digunakan, namun tetap menampung air dalam ember tanpa penutup, sehingga untuk mengurangi tingkat infestasi nyamuk pradewasa perlu sosialisasi kepada petugas kebersihan terkait untuk melakukan pengawasan dan pengendalian vektor dengan kegiatan pemberantasan sarang nyamuk secara berkala.

Suhu air dan $\mathrm{pH}$ merupakan faktor lingkungan yang dapat memengaruhi pertumbuhan jentik..$^{7-9}$

Table 2 Kondisi Lingkungan di Universitas Padjadjaran Jatinangor

\begin{tabular}{lccc}
\hline & pH Air & Temperatur Air $\left({ }^{\mathbf{0}} \mathbf{C}\right)$ & Kelembapan (\%) \\
\hline Rerata & 8,1 & 24,3 & 66,7 \\
Minimum & 4,39 & 21,7 & 47,1 \\
Maksimum & 8,96 & 30,3 & 87 \\
\hline
\end{tabular}


Suhu optimum pertumbuhan nyamuk adalah $20^{\circ} \mathrm{C}$ sampai $25^{\circ} \mathrm{C}$ dan $\mathrm{pH} 6-8 .^{1,6,8}$ Berdasar atas hasil pengukuran didapatkan rerata suhu air dalam kontainer yang diperiksa adalah 24,3 dan pH 8,1. Hal ini menunjukkan bahwa Universitas Padjadjaran memiliki suhu dan $\mathrm{pH}$ pada kondisi optimum yang mendukung pembiakan nyamuk. Air dengan $\mathrm{pH}$ normal adalah kondisi yang baik untuk pertumbuhan jentik, namun akan membunuh jentik jika $\mathrm{pH}$ terlalu asam atau basa. Selain itu, pH asam akan memengaruhi ketersediaan makanan jentik karena gangguan plankton sebagai sumber makanan.,

Faktor lain yang berdampak pada jentik nyamuk adalah kelembapan. Tingkat kelembapan optimal pertumbuhan nyamuk berkisar 81,689,5\%. Universitas Padjadjaran memiliki tingkat kelembapan 66,7\% yang lebih rendah daripada kelembapan yang optimal untuk pertumbuhan jentik. Temuan ini sejalan dengan penelitian Ridha dkk. ${ }^{10}$ di Banjar Baru Utara dan Mading dan Kazwaini ${ }^{11}$ di Lombok yang menemukan jentik pada kelembapan 67,3\% dan 65\%. Hal ini menunjukkan bahwa tingkat kelembapan pada kisaran 65-67\% masih mampu membuat telur berkembang menjadi jentik dengan baik. Simpulan, tingkat kelembapan yang lebih rendah (kelembapan 81,6-89,5\%) masih dapat membuat larva nyamuk tumbuh dengan baik di Universitas Padjadjaran Jatinangor.

\section{Daftar Pustaka}

1. Christophers SR. Aedes aegypti, the yellow fever mosquito: its life history, bionomics and structure. New York: Cambridge University Press; 2009.

2. Dinas Kesehatan Kabupaten Sumedang. Profil Kesehatan. Sumedang: Dinas Kesehatan; 2015.

3. Riandi MU, Hadi UK, Soviana S. Karakteristik habitat dan keberadaan larva aedes spp. pada wilayah kasus demam berdarah dengue tertinggi dan terendah di Kota Tasikmalaya. Aspirator. 2017;9(1):43-50.

4. Van HT. Application of mosquito-proof water kontainers in the reduction of dengue mosquito population in a dengue endemic Province of Vietnam. Asian Pasific J Trop Dis. 2011;1(4):270-4.

5. Faridah L, Respati T, Sudigdoadi S, Sukandar H. Gambaran partisipasi masyarakat terhadap pengendalian vektor melalui kajian tempat perkembangbiakan aedes aegypti di Kota Bandung. MKB. 2017;49(1):43-7.

6. Aziz AT. Household survey of kontainerbreeding mosquitoes and climatic factors influencing the prevalence of aedes aegypti (Diptera: Culicidae) in Makkah City, Saudi Arabia. Asian Pasific J Trop Biomed. 2012;2(11):849-57.

7. Garcia-Sánchez DC, Pinilla GA, Quintero J. Ecological characterization of aedes aegypti larval habitats (diptera: culicidae) in artificial water containers in Girardot, Colombia. J Vector Ecol. 2017;42(2):289-97.

8. Nikookar SH, Fazeli-Dinan M, Azari-Hamidian S, Mousavinasab SN, Aarabi M, Ziapour SP, dkk. Correlation between mosquito larval density and their habitat physicochemical characteristics in Mazandaran Province, Northern Iran. PLoS Negl Trop Dis. 2017; 11(8):1-19.

9. Tallan MM, Mau F. Karakteristik Habitat perkembangbiakan vektor filariasis di Kecamatan Kodi Balaghar Kabupaten Sumba Barat Daya. Aspirator. 2016;8:55-62.

10. Ridha MR, Rahayu N, Rosvita NA, Setyaningtyas DE. Hubungan kondisi lingkungan dan kontainer dengan keberadaan jentik nyamuk aedes aegypti di Kota Banjarbaru. J Epidemiol Penyakit Bersumber Binatang. 2013;4(3):133-7.

11. Mading M, Kazwaini M. Ekologi Anopheles spp. di Kabupaten Lombok Tengah. Aspirator. 2014; 6(1):13-20. 